\title{
What was the Best for an Infant from the Middle Ages to Early Modern Times in Europe? The Discussion Concerning Wet Nurses ${ }^{1}$
}

\author{
Sünje Prühlen
}

W ho was the appropriate woman to care for a nursing infant: the wet nurse or the biological mother? This was a very important question for parents in the Middle Ages and the Early Modern Times. Parents found themselves amidst the conflict of theological and medical views and their own opinions concerning thoughtful baby care. These opinions might have been influenced by books about childcare especially addressed to parents in their language, marriage guides, or variously formulated statements in several other treatises. The following presents preliminary results of a larger research-project focussing wet nurses in the German-speaking Europe.

In the European medieval universities a discussion was carried on about women who breast-fed infants they had not born for remuneration. Many of these arguments were raised in Latin but were in large degree repetitions of those discussions originating in ancient times. This discussion was diverse and had been taken up by doctors, philosophers and theologians. ${ }^{2}$ Of these sources only those which seem of greatest importance or which present special circumstances can be considered in the

1 Special thanks go to Helen Dwyer, New York, USA, who did the proof-reading.

2 E.g. Erasmus von Rotterdam, "Die glückliche Mutter", pp. 274-292, in H. Schiel (Transl.), Erasmus von Rotterdam, Vertraute Gespräche (Colloquia familiaria) (Stuttgart, 1985); "The New Mother Puerpera", pp. 590-618, in C. R. Thompson (Transl.), Collected Works of Erasmus, Colloquies (Toronto, 1997). Alberus Erasmus, Das Ehbüchlein (Frankfurt/Main, 1539), Chapter 4. Pages are not numbered. Marc Pinter (Ed.), Die "Kinderzucht des Hieronymus Schenck von Siemau" (1502) (Hamburg, 1996), pp. 36-39. Adolf Mauch (Transl.), Paolo Baggelardi, Libellus de Aegrituditudinibus infantium, Padua 1472 (Bottrop, 1937), pp. 8-9. Monica H. Green (Transl.), The Trotula. A Medieval Compendium of Women's Medicine (Philadelphia, 2001), pp. 110-111. Erhart Kahle (Transl.), Das Ammenregimen des Avicenna (Ibn Sina) in seinem Qanun (Erlangen, 1980). Contain excerpt from his Liber canonis. Sabine Krüger (Ed.), Konrad von Megenberg, Ökonomik. Book I (Stuttgart, 1973), pp. 78-85. 
following exposition. The inclusion of additional sources would go beyond the scope of this article.

Why were a relatively large number of intellectual involved in this debate starting always with the divinely ordained motherly love and the god-given ability of breastfeeding? Why did parents nevertheless choose the duty of a wet nurse? Why, on the other hand, did many academics point out the importance of making a careful choice? Is it possible to draw conclusions regarding a large number of wet nurses in society from the many treatises which still exist? Why was the topic so widely discussed? Caring for infants by wet nurses may have been prevalent, but up until the present there have been no opportunities at all for quantitative analysis concerning the period from the Middle Ages to the Early Modern Times. The pool for a comprehensive analysis is too small. In the following study another way of providing evidence of wet-nursing will be given, taking into account the period and the characteristics of the sources coming from the German-speaking parts of Europe. Because of the illiteracy of the wet nurses and thus their inability to author their own accounts, they have been the subject of sources written mostly by men. The prime instigator of the discussion in the Middle Ages was the men of learning. Wet nurses were mentioned in passing for example, in hagiographical sources ${ }^{3}$, but there were very few references in testaments or letters. In the later Middle Ages wet nurses were then increasingly mentioned in autobiographical notes, especially in those of citizens or nobleman.

So far up to Middle Ages the discussion about wet nurses in the above mentioned German-speaking region was different from that carried on in other European countries. In the German-Speaking area the wet nurse was called 'Amme' and worked under different conditions than her counterpart in other countries such as France, England or Italy. I would like to refer especially to the research results of Valerie Fildes, Sara Matthew Grieco and Dorothy McLaren. ${ }^{5}$ These historians pub-

3 These kinds of sources are especially available in the early times of the Middle Ages, e.g. Hugeburc von Heidenheim, Vita Willibaldi episcopi Eichstetensis. See as well: Felix's Life of Saint Guthlac. Both cited in Klaus Arnold, Kind und Gesellschaft in Mittelalter und Renaissance (Paderborn, 1980), pp. 97-98.

4 The term 'Amme' or 'Säugamme' did not only mean the Latin word 'nutrix', it was also used for midwives (in German: Hebamme or shortened Amme). The word 'Amme' is verifiable in the Old and the Middle High German. Jacob Grimm, Wilhelm Grimm, Deutsches Wörterbuch, 1 (Leipzig, 1854), col. 278. The German 'Amme' and the Iberian 'ama' has nearly the same meaning and should trace back to the Latin expression which little children babble. Cp. "Ama”, Dicionario crítico Etimológico Castellano e Hispánico, 1 (Madrid, 1980), 226-227, Carolina Michaelis de Vasconcellos, "Randglossen zum altportugiesischen Liederbuch”, Zeitschrift für romanische Philologie, 20 (1896), 162-163.

5 Valerie Fildes, Wet-Nursing. A history from antiquity to the present (Oxford, 1988); Valerie Fildes, Breasts, Bottles and Babies. A History of Infant Feeding (Edinburgh, 1986); Sara F. Matthews Grieco, "Breastfeeding, Wet Nursing and Infant Mortality in Europe (1400-1800)", Historical Perspectives on Breastfeeding (Florence, 1991), 15-62; Dorothy McLaren, "Marital fertil- 
lished their findings with other sources of greatest importance in the 1980s and 1990s. They have provided truly fundamental research in this area, especially for this era. There are no comparable German authors. ${ }^{6}$ The findings of Fildes, Grieco and McLaren were based mostly on documents of the already mentioned countries. Beyond those findings of the mentioned European countries it is possible to find German sources documenting wet nurses as well as specific characteristics and circumstances which should receive attention. The author who perhaps had the most influence on parents, judging from the new edition of his books, is Bartholomäus Metlinger (c 1440-1492). He published the first paediatric book in German. It is one intention of this exposition between the demand for and the existence of wet nursing.

In contrast to England, for example, many wet nurses stayed in the houses of their German employees. ${ }^{7}$ Wet nurses also took care of foundlings who were not usually sent to the countryside to stay with the wet nurses' families. These wet nurses were paid, controlled and supervised by city councils because such infants were foundlings or orphans. In the accounts of Zwickau, Saxony, a wet nurse who came from a respectable family had been listed since the year 1500. The town authorities not only paid the fee of the wet nurse but also paid for the baby's clothing, baptism and, if necessary, funeral. ${ }^{8}$

In this period foundling hospitals were not found everywhere in Germany. In northern German cities such as Hamburg a hospital was founded in 1595 solely for orphans of the city's inhabitants. In the southern part of Germany, for example in Munich, poor but married mothers had the possibility to deliver their babies in a special house. After their mothers died these abandoned child remained outside the city walls until they were weaned. Sometimes the families had to pay for the basic necessities of the infants. In the area of the Upper Rhine there were foundling hospitals in earlier periods. Some of the foundlings, for example in Strasbourg stayed in the country with their wet nurses as it was common in the proximate France.'

ity and lactation 1570-1720", M. Prior (Ed.), Women in English society 1500-1800 (London, 1985), 22-53.

6 Some authors only give a chapter in their treatises about wet nurses. E.g. Frank Meier, Mit Kind und Kegel. Kindheit und Familie im Wandel der Geschichte (Ostfildern, 2006), pp. 99104.

7 Cp. Valerie Fildes, “The English Wet nurse and her role in infant care 1538-1800", Medical History, 21 (1988), 143-144. Same, Breasts, Bottles and Babies (Edinburgh, 1986), pp. 152-156.

8 Ute Rosenbaum, Liebestätigkeit und Armenpflege in der Stadt Zwickau. Ein sozialhistorischer Abriss von Mittelalter und beginnender Neuzeit (Hamburg, 1999), pp. 41-42. In Basel, Switzerland, the hospital put a foundling into a wet nurse's care. Michaela von Tscharner-Aue, Die Wirtschaftsfïhrung des Basler Spitals bis zum Jahre 1500 (Basel, 1983), p. 50.

9 E.g. the biography of the abbot saint Robert of Chaise-Dieu ( $\dagger 1065)$ written by Marbod of Rennes (c. 1035-1123). The saint Robert did not accept the wet nurse's milk, not because 
Other foundlings were raised in orphanages. The city council also paid the allowance in the nearby monastery of Staßfeld. As well, the alderman of Frankfurt/Main placed their foundlings in Staßfeld, supervised the wet nurses until the children were weaned and could be returned to their towns of origin. ${ }^{10}$ In contrast to the whole German-speaking Europe wet nurses who stayed in the country were the exceptions, for example in England. For foundlings a wet nurse was a necessity and increased the chance of survival. ${ }^{11}$ These individual women might not have been the main interest in the discussion about wet nurses and the value of nursingmothers. But with whom were the academics really concerned?

\section{Wet Nurses and Wet-Nursing in German Sources}

There is documentary evidence of only a small number of few wet nurses for this period; for many more there is none. More information about the circumstances of wet nurses can be found especially in autobiographical notes, as in the case of Hartmann Schedel (1440-1514), who acquired a Master of Arts and a Doctor of Medicine in adulthood. ${ }^{12}$ Schedel's wet nurse is documented, because she stayed in the employer's house. She must have been seen almost as a family member and thus became a subject of the oral tradition, as evidenced by Schedel's having passed down facts related to her as an adult. Schedel mentioned his own wet nurse, Margareta, who came from Adorf - a town in Bohemia about $150 \mathrm{~km}$ away from her place of employment in Nuremberg. In addition Schedel put on record several wet nurses of his own children. In the Middle Ages and the beginning of the Renaissance wet nurses ranked higher in the social hierarchy than the maidservant or the

of the smell but because of the wet nurse's sins. Cp. Klaus Arnold, Kind und Gesellschaft in Mittelalter und Renaissance (Paderborn, 1980), p. 103.

10 Ulrich Knefelkamp, Das Gesundheits- und Fürsorgewesen der Stadt Freiburg im Breisgau im Mittelalter (Freiburg, 1981), p. 149.

11 Gerry Hill has pointed out the importance of wet nurses and their influence on the survival rate of children. He omits in his essay the time of the Middle Ages. Idem., et al., "The Medical and Demographic Importance of Wet-Nursing", Canadian Bulletin of Medical History, 3 (1987), 183-193. John Knodel and Hallie Kintner analysed the modern times when the breastfeeding patterns changed. Idem, "The Impact of Breast feeding patterns on the Biometric Analysis of Infant mortality”, Demography, 14 (1977), 391-491.

12 Hartmann Schedel, Hartmann'sche Familienbuch/Familienchronik. Staatsbibliothek Berlin, Cod. Germ. $2^{\circ} 4472$, fol. 16. Hartmann Schedel is author of the Chronicle of the world which was first published in Nuremberg 1493. His library holdings are known to have been considerable. Hartmann Schedel, Weltchronik (Nuremberg, 1493). Richard Stauber, Die Schedelsche Bibliothek. Ein Beitrag zur Geschichte der Ausbreitung der italienischen Renaissance, des deutschen Humanismus und der medizinischen Literatur (Freiburg, 1908, Reprint Nieuwkoop, 1969). 
menial, but they were still part of the menial staff. ${ }^{13}$ In some payment records only wet nurses were itemised. Apparently the merchant Michel Behaim (1459-1511) from Nuremberg only paid his wet nurse, Kunne. ${ }^{14}$

A wet nurse had less and lighter work to do than the other servants as it was recommended by the doctors. The academics dealing with the subject asked the employer to employ wet nurses during lactation. Parents were to be aware of the possible deleterious effect which hard labour on the part of the wet nurses could have upon the quality of milk. On the other hand laziness could be bad for the quality as well.

These are not the only examples from civic or noble families ${ }^{15}$, but because of the low rank of the wet nurses, they have not often been listed. A future desideratum will be the precise interpretation of autobiographical notes to find reference to more wet nurses. In the upper classes the duties of wet nurses were more common, but it would be careless to assume that every baby would have been suckled by a wet nurse. While there is a great uncertainty, it is nevertheless possible to find in the sources more indications besides the wet nurses' names or the term Amme. Thus it may be possible that the academic and the public debates were closer to reality than it now seems. Why the topic has been discussed so widely in academic circles cannot be answered, but this might provide stimulus for looking into other lines of argument.

Many German writers of autobiographies of this period listed especially in registers the name and the date of birth of their own children. ${ }^{16}$ The birth intervals in the example below are unusually short and do not correspond to the natural infertility of the biological mother in times of lying-in, lactation and normal pregnancy. Most of these children survived infancy. Therefore it can be assumed that they were born following a normal pregnancy. Stillbirths are noted in the sources and in some cases there are indications of premature births or birth defects. Some of these infants died, but especially in the case of premature births after seven months of

13 See the register of the professor's servants from the University of Helmstedt 1584. Album Academiae Helmstadiensis, ed. by Paul Zimmermann, 1, 1 (Leipzig, 1926, Reprint Nendeln, 1980), p. 53. Also Max Hermann (Ed.), Albrecht von Eyb, Ehebüchlein (Berlin, 1890), p. 19.

14 Q.v. J. Kamann, Nürnberger Haushaltungs- und Rechnungsbücher aus dem 15. und 16. Jahrhundert (Nürnberg, 1888), p. 17.

15 E.g., the memoirs of Helene Kottanerin are thought to be the earliest of a German woman. Karl Mollay (Ed.), Die Denkwürdigkeiten der Helene Kottanerin (1439-1440) (Wien, 1971). pp. 18-22.

16 E.g. Gudrun Litz (ed.), "Familienbüchlein Spengler", in Berndt Hamm, Lazarus Spengler (1479-1534) (Tübingen, 2004), pp. 361-402. Several datas from the sources are listed in Klaus Arnold, "Kindertotenbilder - Neue Zugänge zu Leben und Tod von Kindern im späten Mittelalter und in der frühen Neuzeit", K. W. Alt, A. Kemkes-Grottenthaler, eds., Kinderwelten (Köln, 2002), pp. 215-219. With this pool it might be possible to find out the infant mortality of these specific population groups. 
pregnancy the authors noted this special circumstance and the will of the baby to live. These autobiographies may provide an under-utilised pool of information especially for the Middle Ages. After the Reformation Church records in the German-speaking Europe, as opposed to other regions, are another source of information which has become popular for such research.

The first postpartum menses is possible after two months and ovulation therefore occurs earlier. Exclusive breastfeeding prolongs this period although this is dependent upon the number of times a child is nursed in a day. Some physicians in the Middle Ages and the Renaissance advised a mother - or the wet nurses - to feed the child not more than three times a day; others never fixed a limit. This might point to an element of uncertainty. Breastfeeding exclusively during night and day provides a high probability of contraception for the first six months post partum. ${ }^{17}$ In this specific point it may be possible to combine modern medical knowledge and historical data. The Brandis family from Hildesheim, lower Saxony, is a good example for this combination with a reverse. In their case the birthday of every child as well as some wet nurses are documented. The first seven of the 15 children (two pairs of twins) were born to one mother in intervals of 12 and half and 14 and half months, the others between 16 and 22 months. The children were born alive and survived infancy. In each circumstance the intervals of the births are unnaturally short, given that the biological mother breastfed every child. ${ }^{18}$

Another aspect to be considered is food. At this time the only way of nourishing babies to assure a high survival rate was breastfeeding. In the German archives especially in the Early Modern period - recipes for formula for use at the time of weaning were found ${ }^{19}$, but there was no reference to a formula using milk from ani-

17 The Lactational Amenorrhoea Method (LAM) is one method of contraception. The efficacy of the method for full breastfeeding women depends on the times of lactation. Alan S. McNeilly, "Lactational Endocrinology: The Biology of LAM", Advances in experimental medicine and biology, 503 (2002), 199-206. Intensive Breastfeeding of six and more times a day causes a Lactational Amenorrhoea up to 18 month postpartum. C. Keck, C. Kissel, "Regulation der Laktation”, Gynäkologische Endokrinologie, 3 (2004), 130-131. Dorothy McLaren analysed others sources which are not available for a comparable time in German-speaking Europe. Idem, "Nature's contraceptive. Wet-Nursing and prolonged lactation: the case of Chesham, Buckinghamshire 1578-1601", Medical History, 23 (1979), 426-441.

18 Q.v. Sünje Prühlen, "Alse sunst hir gebruchlich is" (Bochum, 2005), pp. 73-75, Diagram p. 363.

19 There are a lot of prescriptions or recipes for weaning shortly after the accouchement. In the Heidelberg University Library there are many popular scientific treatises available which were passed over as paper manuscripts. Many recipes are written in German and copied several times. Most of these documents were undirected and anonymous. Some gynaecological prescriptions are titled "For women, who wean their child because the milk hurts, the child died or she doesn't want to breastfeed by herself" Cp. Heidelberg University Library, Cod. Pal. Germ. 236, fol. 122r, Cod. Pal. Germ 252, fol. 147r, Cod. Pal. Germ. 288, fol. 96r, 101r, Cod. Pal. Germ. 702 , fol. $5 \mathrm{v}$. There are also recipes to recover maternal ability of breastfeeding as well as to increase the lactation of the wet nurse. Cp. ibidem, Cod. Pal. Germ. 195, fol. 174r, Cod. Pal. 
mals. ${ }^{20}$ Thomas Platter (1499-1582), a Swiss author from the beginning of the sixteenth century, wrote in his autobiographical notes that he had been fed via a horn like those used for older children. His mother had not had the physical ability to suckle her little boy, so he received cow's milk from a cow horn. This method of nutrition had been essential for him. Normally this procedure resulted in the deaths of many infants because cow's milk was unsuitable because it could not be digested by a young child. Additionally, this animal milk was suspected of transferring the attributes of the host to the child. ${ }^{21}$

Feeding an infant from a horn or a suckle pot presented also a hygienic problem. Some mothers were afraid that their breasts became altered by feeding their own child directly from their nipples. So they decided to use a suckle pot or a horn for the breast-milk in order to preserve their physical beauty. ${ }^{22}$ The employment of a wet nurse, therefore, did not seem to be a necessity but rather a luxury. Sometimes, however, the employment of a wet nurse has been a necessity if, for example, the biological mother died while giving birth or as a result of a caesarean section ${ }^{23}$ or during the postnatal period. In these cases the chance of survival for the baby increased with the services of a wet nurse.

Apparently a greater number of wet nurses must have stayed in the employers' homes than was recorded in the autobiographical notes or in other registers. Wetnursing was a more important factor in taking care of an infant than the focus of

Germ 225, fol. 265r, 273v, Cod. Pal. Germ. 254, fol. 197v, 202v, 203r, Cod. Pal. Germ. 256, fol. 302r, Cod. Pal. Germ 270, fol. 68r-70r, Cod. Pal. Germ 288, fol. 7r, Cod. Pal. Germ 299, fol. 24r. A catalogue to some of these recipes can be found under the following address: http://archiv.ub.uni-heidelberg.de/volltextserver/portal/med-hs/ (12.06.2006)

20 Thomas Platter, Hirtenknabe, Handwerker, Humanist. Die Selbstbiographie 1499 bis 1582, Heinrich Boos, ed. (Nördlingen, 1989), p. 8.

21 Thus it might be possible that for this reason no experiment was conducted with animal milk at all. Konrad Bitschin (c 1400 - after 1464) gave an example of a wet nurse who fed the child entrusted to her care with pig-milk. In adulthood this child behaved like a pig. Richard Galle (Ed.), Konrad Bitschins Pädagogik (Gotha, 1905), pp. 17, 104.

22 Suckle pots and horns are known from the ancient times. Hans Schadewaldt, Geschichtliche Übersicht über die zur Säuglingsernährung verwandten Geräte. Wissenschaftliche Ausstellung, 54. Tagung der Deutschen Gesellschaft für Kinderheilkunde 1954. Hermann Brüning, Geschichte der Methodik der künstlichen Säuglingsernährung, nach medizin-, kultur- und kunstgeschichtlichen Studien (Stuttgart, 1908). See as well an English depiction of a woman who is feeding an older child from a horn. Bari Hooper, "A Medieval Depiction of Infant-feeding in Winchester Cathedral”, Medieval Archaeology, 4 (1996), 230-233.

23 The first successful caesarean which mother and child survived in German-speaking regions is documented in 1610 in Wittenberg, Saxony. Gottfried Trautmann, Der Kaiserschnitt des Jeremias Trautmann im Jahre 1610 (Wittenberg, 1978). There might have been more successful caesareans but they were subjects of oral tradition and not documented by eyewitnesses. E.g. Oswald Feis, "Bericht aus dem Jahre 1411 über eine Hebamme, die angeblich 7 Kaiserschnitte mit gutem Erfolg für Mutter und Kind ausgeführt hat", Sudhoffs Archiv für Geschichte der Medizin, 20 (1928, Reprint 1965), 340-343. 
historical research up to now would indicate. It may be possible to approximate patterns of family life in this period by data analysis of the available sources.

It is not easy to provide evidence regarding the knowledge of the correlation of breastfeeding to fertility, conception, and minimising birth intervals in the sources of this period. The church could have disapproved of such knowledge because it might be misused. In his book of 1433 the German town clerk, Konrad Bitschin from Danzig (now Gdansk, Poland), found fault that an increasing number of women had their children fed by wet nurses because they did not want to stay sexually abstinent during lactation as the church recommended. ${ }^{24}$ Medicine encouraged this point of view by asserting that sexual intercourse could affect the quality of the breast-milk and therefore the state of health of the child. This concerned the biological mother as well as the wet nurse. Against the background of Bitschin's observation it may also be possible that there was a common knowledge of a Jewish source of Regensburg from the fifteenth century. ${ }^{25}$ Jewish families were advised to hire a wet nurse if there had not been enough children born to glorify God. This was a part of the oral tradition. This information could have been transferred by a dialogue between Jews and Christians.

This might be sufficient reason for parents to hire a wet nurse, but the theologians, philosophers and physicians had many arguments against wet-nursing. In addition to the above mentioned antique heritage of Hippocrates ${ }^{26}$ and Galen ${ }^{27}$ and the medieval Islamic influences of Rhazes, Avicenna, Constantinus of Africa and Averroes, it is possible to find special German contributions to the discourse about birth and childhood as well. ${ }^{28}$

\section{The Academic Discussion on Breast Feeding}

Following examples from antiquity many authors started their disquisition of breastfeeding with a description of the wonderful loving care that only the biologi-

24 Richard Galle (Ed.), Konrad Bitschins Pädagogik (Gotha, 1905), pp. 17, 104. Ole J.

Benedictow explained the long term and wide spread discussion about breastfeeding women who should stay abstain from sexual intercourse. Cp. Ole J. Benedictow, "On the Origin and spread of the Notion that Breast-Feeding Women should abstain from sexual Intercourse", Scandinavian Journal of History, 17 (1992), 65-76.

25 Susanne Borchers, Jüdisches Frauenleben im Mittelalter. Die Texte des Sefer Chasidim (Diss., Köln 1998, Frankfurt, 1998), pp. 236-237.

26 Q.v. Corpus Hippocraticum, De natura pueri.

27 Q.v. Erich Beintker (Transl.), Galenos Gesundheitslehre, 1-3 (Stuttgart, 1939), pp. 34$35,38-41$.

28 Bartholomäus Metlinger mentioned these examples by name in his preface. Idem, Ain vast nutzlich regiment der iungen kinder (Augsburg, 1511). Pages are not numbered. 
cal mother could bring the child through the process. ${ }^{29}$ What could be more advantageous for an infant? The mother could pass on her love and also her character through the milk even as she had done via her blood in the womb. The blood was merely transformed into the milk. God created a woman with breasts and the possibility of lactating a newborn. So she could and should nourish her newborn baby until the child could tolerate solid food. This was always a sign and a symbol of motherly love, a wonderful devotion between mother and child. The theologian and musician, Heinrich von Laufenberg (c 1390-1460), added by way of explanation that the child should suck with "lust" at the breast of his mother ${ }^{30}$ but this was never the only reason for nursing the biological infant. During gestation the character of a child was formed by the character of the mother. ${ }^{31}$ Afterwards the nursling could come into contact with the character of a woman who was a stranger. In some cases this could be fatal - not in the sense, that the child really died - but that the entire life of the baby could be modified. ${ }^{32}$

So it was very important - if the real mother did not or could not suckle her own infant - to select a wet nurse very carefully. In the Middle Ages the doctor of medicine and sometimes other men of learning had the authority and the knowledge of childcare to enable them to instruct parents and midwives. In later times these men also placed wet nurses in the homes of the employers.

This task of the physicians changed when the German authors did not write in Latin anymore. Bartholomeus Metlinger is one of the most famous doctors of his times, as he describes himself in one of his later printings of his helpful regimen for young children. ${ }^{33}$ Metlinger was the first paediatrician in Germany and worked in Noerdlingen (now in Swabia) and Augsburg (now in Bavaria) and published his advice in his 'Regiment der Kinder', reprinted several times since the original in $1473 .^{34}$

29 Albertus Magnus (c 1200-1280) summarized in his sermon that Mary had been a mother and wet nurse in one person. Under no circumstances she would have handed over Jesus to a real wet nurse. Albertus Magnus' Sermon about Luke 11,27 cited in Klaus Arnold, Kind und Gesellschaft in Mittelalter und Renaissance (Paderborn, 1980), p. 120.

30 Heinrich Laufenberg, Versehung des leibs (Augsburg, 1491), Chapter 6. The pages are not numbered. Ibidem.

31 This belief came out of the ancient world and has been codified in the middle ages.

32 Sabine Krüger (Ed.), Konrad von Megenberg, Ökonomik. Book I (Stuttgart, 1973), p. 78; Adolf Mauch (Transl.), Paolo Baggelardi, Libellus de Aegrituditudinibus infantium, Padua 1472 (Bottrop, 1937), p. 9

33 Bartholomäus Metlinger, Ain vast nutzlich regiment der iungen kinder (Augsburg, 1511).

34 Bartholomäus Metlinger, Ein regiment der jungen kinder, Facsimile of the print from 1497 (Zürich, 1976); Ursula Gray, Das Bild des Kindes im Spiegel der altdeutschen Dichtung und Literatur (Frankfurt/Main, 1974). The pages of the Facsimile are not numbered. - As can be seen in the following compilation of theological and medical authors: Later Metlinger's treatise was 
Metlinger's proposition never changed in any of the editions unlike the different German idioms. He gave advice for parental care until the child was seven years old. His audience was made up of parents - mostly out of the bourgeoisie as in a trading town like Augsburg. In the preface he addressed his book explicitly to mothers and fathers. Who actually read the book and followed the instructions is as yet unknown.

The $2^{\text {nd }}$ chapter of his regimen was titled: "How you should nourish and feed a child". There he pointed out to the parents that a baby should not get the milk of the biological mother until the fourteenth day of the maternal childbed. In that period the quality of the milk would not be good for the infant. He proposed that young puppies should suck the milk out of the mother's breasts. ${ }^{35}$ Authors of Antiquity recommended that another woman could suck this milk. Soranos, for example, advised waiting a period of about two or three days time after the birth. ${ }^{36}$ This paradigm has been taken over in part as Metlinger wrote not to suckle the children for the first three days of their life. When a wet nurse was involved, this period could be extended.

Metlinger advised that if it was not possible for the mother to take a break in lactation, she should suckle the infant with a little bit of honey in his mouth. This would protect the baby against the bad quality of her milk. Who nursed the newborn in the time when the mother herself was not to nurse the infant at all? Nobody knows. These women - like those in Metlinger's case - were not called wet nurses in contrast to the practice of ancient authors like Soranos. They may have simply been women who remained in the puerperium longer than had the natural mother herself. So the term wet nurse was used for women who took care of little infants for a longer time.

Other authors as well as Metlinger tell us more about the proper choice of a wet nurse. ${ }^{37}$ The selection criteria varied only a bit among authors. The age of wet

also a part of the German pharmaceutical book for the matrimony (in German 'Ehestandsarzneibuch') together with the versions of Eucharius Rösslin's (c 1470-1526) textbook Rosarium for Pregnant Woman and for Midwifes ('Schwanger Frawen und Hebammen Rosengarten'). The Rosarium was the first really successful textbook for midwifery in German. This miscellany contains a woman's drug book - Frawen Artzeney - by Johannes de Cuba (1484-1503), a physician specialising in medicinal herbs, the Secrecies ('die Heimlichkeiten der Frauwen') by medically educated theologian, Albert the Great (1193-1280), and the Fortuities of Pregnant Women who causes concerns, ('Von sörglichen Zufällen der schwangeren Frauen') by the Italian obstetrician Ludovico Bonaccioli (-1540). Q.v. Ehestandsartzneybuch (Erfurt, 1542).

35 Ursula Gray, Das Bild des Kindes im Spiegel der altdeutschen Dichtung und Literatur (Frankfurt/Main, 1974), p. 220.

36 Owsei Temkin (Transl.), Soranus' Gynecology (Baltimore/London, 1991), p. 88.

37 E.g. Sabine Krüger (Ed.), Konrad von Megenberg, Ökonomik. Book I (Stuttgart, 1973) (Monumenta Germaniae Historica, Scriptores III, 5/1), p. 78. 
nurses should have been between 20 and 35 years. ${ }^{38}$ Metlinger defines the best age about $25 .^{39}$ The wet nurse's child - ideally a healthy boy - should be six to twelve weeks old so that the mother would be through the anastasis period. The wet nurse should be a good fit to the child's physical and mental abilities so that the parents using her services would not bring illness to the child. This maxim was derived from the Hippocratic idea of the humoral pathology.

A good wet nurse had an exemplary character, was not choleric, was moderate in all walks of life, especially in her eating and drinking habits. During the time of nursing a woman - whether biological mother or wet nurse - was not to have sexual contact at all. ${ }^{40}$ This was thought to affect the quality of the milk as well as to promote illness and renewed pregnancy ${ }^{41}$. During the time of distress mothers whether biological mother or wet nurse - aided one another. In 1541 the Swiss naturalist and physician, Conrad Gesner (1516-1565), noted in his brief book about milk and milk products, which also included human milk, that wealthy families should hire several wet nurses. If a wet nurse, for example, became ill, the problem thus could be solved more easily. ${ }^{42}$ The question concerning what happened to the biological child of the wet nurse in this period cannot be answered because at this point of research there are no sources at all. Wet nurses may not all have been mothers who had given birth to a living child. Their babies may have died shortly after birth or have been stillborn during the latest stages of pregnancy. The nurslings of the wet nurses might have resided in the house of the employers where nobody talked about it. ${ }^{43}$

Metlinger advised that in the case that the wet nurse became pregnant the child should be weaned to avoid becoming ill. In this case the baby should be fed only

38 Q.v. Erhart Kahle (Transl.), Das Ammenregimen des Avicenna (Ibn Sina) in seinem Qanun (Erlangen, 1980), pp. 6, 17; Adolf Mauch (Transl.), Paolo Baggelardi, Libellus de Aegrituditudinibus infantium, Padua 1472 (Bottrop, 1937), p. 9.

39 Metlinger recommended a wet nurse being between 20 and 30 years of age, ideally 25 years old. Bartolomäus Metlinger, Ain vast nutzlich regiment der iungen kinder (Augsburg, 1511), Chapter 2.

40 Q.v. Richard Galle (Ed.), Konrad Bitschins Pädagogik (Gotha, 1905), pp. 17, 104.

41 See as well a German prescription in Heidelberg University Library about pregnancy being injurious to the child as well as a woman being unchaste during the nursing period. In this context Galen was mentioned by name. Cod. Pal. Germ. 292, fol 16r-16v. Q.v. gloss. No. 9.

42 Carl-Ludwig Riedel (Ed.), Conrad Gesner, Büchlein von der Milch und den Milchprodukten. Libellus de lacte, et operibus lacteriis, philologus pariter ac medicus (Mönchengladbach, 1996), p. 48. This seems to be only advice.

43 Only in later times can the circumstances of the infant and the family be focussed. Upon the eighteenth century wet nurses from the surrounding area of Hamburg left their children at home in their families with the father and stayed with the employers in the city. The wet nurse was so well paid that she could support the whole family. L.A.G. Schrader, "Beherzigungen über die moralischen und politischen Folgen des Ammendienstes in großen Städten auf die umherliegenden Distrikte“, Schleswig-Holsteinische Provinzialberichte, 1 (1787), 457-461. 
mush. ${ }^{44} \mathrm{He}$ went on recommending as well that the child should receive "more mush" if the parents or the wet nurse were confronted with a problem. He did not explain this further. Metlinger wrote that the infant should be fed a mixture of the wet nurse's milk and mush until the first baby teeth came in at the age of two. $\mathrm{He}$ never gave a fixed date for the beginning the regimen of milk and mush, but apparently this was to happen soon after birth, i.e., at a very young age for the suckling baby.

Metlinger was an author who gave good advice with regional distinctions. In the area around the cities of Augsburg and Noerdlingen it might have been normal to feed babies cereals at a very young age. For centuries the death rate in this area and as well in some regions of Wurttemberg was extremely high in comparison to other regions of Germany because children there were never fed with milk at all. ${ }^{45}$ At the beginning of the nineteenth century physicians guessed an atrophy of the female breasts because they surmised that the mammary glands became mutated after a long period of disuse for generations. The doctors thought that women lost their ability to nurse their children. ${ }^{46}$ When in history nutrition with grain began in these regions is unknown. ${ }^{47}$ It may be possible to find indications by studying the mortality rate in parish registers and evidence in other documents. This is a desideratum for future research because the relation between Metlinger and his audience has never been focused upon. It is not clear whether Metlinger was acting on someone else's suggestion or if he himself initiated a development which resulted in the abandonment of breastfeeding across broad levels of the population.

Bartholomäus Scherrenmüller (c 1450 after 1493), medical professor at the University of Tübingen translated into German in 1493 on behalf of Earl Eberhard im Bart of Wurttemberg (1445-1492) the Latin version of the health regimen of William from Saliceto (c $1210-$ c 1285). ${ }^{48}$ William from Salicetos wrote the original De conservatione sanitatis a die conceptionis usque ad ultimum vite senij in the thirteenth century. Differing to Metlinger's broad target group, this German version has only been designed for court. Saliceto or Scherrenmüller advised that

44 Ursula Gray, Das Bild des Kindes im Spiegel der altdeutschen Dichtung und Literatur (Frankfurt/Main, 1974), p. 221.

45 Georg Mayr, "Die Sterblichkeit der Kinder während der ersten Lebensjahre in Süddeutschland, insbesondere in Bayern", Zeitschrift des königlich Bayerischen statistischen Bureau, 2 (1870), 201-202.

46 Reinhold Altmann, Über die Inactivitätsatrophie der weiblichen Brustdrüse (Diss. Munich 1888, Berlin, 1888).

47 Hugo Bernheim remarks that there were reports in the year 1524 that in these regions the women did not nurse at all. Idem, "Schwankungen der Sterblichkeit in Bayern und Sachsen und deren Faktoren", Zeitschrift für Hygiene, 4, (1888), p. 575, note 1.

48 Wolfram Schmitt, Bartholomäus Scherrenmüllers Gesundheitsregimen (1493) für Graf Eberhart im Bart, (Diss. Heidelberg, 1970). It contains: Wilhelm von Saliceto, 'De conservatione sanitatis a die conceptionis usque ad ultimum vite senij' = 'Summa conservationis et curationis'. 
the infant should only get breast milk until the child was between six and twelve months old. ${ }^{49}$ Then the mother or the wet nurse could nourish the child additionally with rice pudding, dunking bread, and a little bit of tender, white meat. This seemed quite early because as Avicenna said - like Soranos as well ${ }^{50}$-, the child should be weaned by the age of two. ${ }^{51}$ The theologian and natural scientist, Konrad von Megenberg (1309-1374), however noted in his house book ('Ökonomik') of 1352 that only poor parents were forced to nourish their babies for a period of one and half years or longer. ${ }^{52}$ Children who suckled for a longer while would have stronger physiques. Heinrich Laufenberg recommended that the child should be fed with milk alone until a tooth appeared. ${ }^{53}$ There is no documentary evidence as to how long children really were wet-nursed or breastfed by their biological mothers. Most of the wet nurses stayed for a longer period of time - two or three years - in the homes of the employers. As the child became older the wet nurse played with him/her and taught him/her to speak and to walk. ${ }^{54}$ She took care of him/her, like she did before, for 24 hours a day. They slept in the same room and the wet nurse swaddled, bathed, cradled and calmed the infant.

\section{The Selection and Supervision of a Wet Nurse}

The biological parents supervised the wet nurse and the child. If something changed in the behaviour of the child, the employers had the duty to control the milk by taste, smell and appearance as at the onset of the employment. The Swiss naturalist and physician, Conrad Gesner, summarized all criteria from the ancient authors. ${ }^{55}$ The milk of a good wet nurse had to be sweet at all times, white in colour and not too thick or thin. A colour of light green or yellow should be a warning to the parents. On a fingernail the milk should stay in a drop. If the breast milk would taste acrid or salty, this could be a sign for illness of the wet nurse. Parents were also to be attentive if the liquid was malodorous or foamy. In these cases the wet nurse

49 Ibid., pp. 58, 112.

50 Owsei Temkin (Transl.), Soranus' Gynecology, (Baltimore/London, 1991), pp. 117-118.

51 Erhart Kahle (Transl.), Das Ammenregimen des Avicenna (Ibn Sina) in seinem Qanun (Erlangen, 1980), p. 25.

52 Sabine Krüger (Ed.), Konrad von Megenberg, Ökonomik. Book I (Stuttgart, 1973), p. 83.

53 Heinrich Laufenberg, Versehung des leibs (Augsburg, 1491), Chapter 6.

54 Sabine Krüger (Ed.), Konrad von Megenberg, Ökonomik, Book I (Stuttgart, 1978), pp. 83-85. Wolfram Schmitt, Bartholomäus Scherrenmüllers Gesundheitsregimen (1493) für Graf Eberhart im Bart, (Diss. Heidelberg, 1970), p. 59.

55 Carl-Ludwig Riedel (Ed.), Conrad Gesner, Büchlein von der Milch und den Milchprodukten. Libellus de lacte, et operibus lacteriis, philologus pariter ac medicus (Mönchengladbach, 1996), pp. 48-49. 
was to milk the liquid out of her breast. If the quality was still not satisfactory, the child was to receive other breast milk, or as Metlinger proposed, the infant should be weaned.

The wet nurse was to be in good physical condition. For the acceptance test Metlinger set even higher standards. The parents were to look very carefully at the physiognomy of the wet nurse. First of all the parents were to appraise the chest. The wet nurse should have a strong neck. If the wet nurse passed this test and was employed the parents were responsible for her health, the health of the child and the quality of the milk. Metlinger, therefore, offered much advice in this area. The wet nurse was to get good and healthy food with light white meet, grain, and fresh vegetables (except for onions and garlic). The meal was not to be hot and spicy. She should drink mild wine mixed with water and, and for the more northern German regions Metlinger recommended beer. He pointed out to the parents that beer could water down the breast milk. On the other hand beer could promote lactation. ${ }^{56}$ If the wet nurse or the infant would have problems with their stomachs, their digestion or their appetite, the wet nurse should drink dill, fennel and caraway tea. If the child suffered from constipation the wet nurse should get an enema. The infant should be wet-nursed very carefully and properly so the baby grew, rested easily and would not cry for anybody. If the little one was not pleased with the situation, parents should first consider the child and then the wet nurse. If the employed woman showed signs of a bad character ${ }^{57}$ or poor behaviour, the father was to educate the wet nurse. If the parents followed all instructions, the child would be sane, although not if the biological mother were taking care of him the entire time.

Thus the discussion about wet nurses left the medical faculties and the authority of men of learning. Perhaps the authority to place a wet nurse in the employers' homes changed at that point also. There had been a necessity to educate parents, and there had been a market for the wet nurses as well. This wet nurse market increased in German-speaking Europe in the late eighteenth and the beginning of the nineteenth centuries. ${ }^{58}$ Then the whole system moved away from the employers' houses and the family relationship to foundling hospitals with permanent wet nurses. Wet nurses became more and more anonymous and left also the oral tradition of the family atmosphere. Physicians showed more interest in increasing the

56 Berthold Koletzko, Frauke Lehner, "Beer and Breastfeeding", in B. Koletzko, et al., eds., Short and Long Term Effects of Breastfeeding an Child Health (New York, 2000), pp. 23-28.

57 About the importance of character and the analogy between child and wet nurse see as well Sabine Krüger (Ed.), Konrad von Megenberg, Ökonomik. Book I (Stuttgart, 1973), p. 78.

58 The expanding discussion about wet-nursing in Germany has already been the subject of research. Johanna-Luise Brockmann, "Ammentätigkeit in Deutschland (1750-1925). Eine Problemskizze zu einem vernachlässigten Thema der Sozialgeschichte", Zeitschrift für Pädagogik, 28 (1982), pp. 695-714; see as well: Wolfram Malte Fues, "Amme oder Muttermilch? Der Disput um das Stillen in der frühen deutschen Aufklärung “, Aufklärung, 5 (1990), pp. 79-126. 
milk yield of the wet nurse $e^{59}-$ an indicator of the depersonalization of the wet nurse.

\section{Summary}

The discussion concerning wet nurses in the Middle Ages and the Early Modern Times was widely diverse. Theologians, physicians and philosophers offered advice to the public. In earlier periods it was assumed that the literate public could read Latin. In German-speaking Europe the audience changed with the publication of the first paediatric book in German by Bartholomäus Metlinger in 1473. He gave advice about the selection of the right wet nurse and her supervision during her time of residence directly to parents in their own language. His advice about childcare did not agree with the opinions of other authors from the same period. It might be possible to conclude, however, that Metlinger's advice dramatically changed childcare in some regions because centuries later physicians still thought that the mothers could not nurse their own children anymore. In this society the women did not feed their children with mother milk. Was this the result of the debate about the divinely-ordained motherly love, the God-given ability of nursing and the right choice of childcare? This is a desideratum of the future research.

Authors like Metlinger, on the other hand, established criteria in this lively discussion as how to select a wet nurse. Autobiographical notes may provide references to a more realistic view on the phenomenon "wet nurse". Most of these women stayed in the employers' homes which complicated on the one hand, finding evidence of their existence, and on the other hand, complicated the circumstances of life of their biological child. The first complication maybe reduced by looking more at the facts which exists in combination to the biological ability of fertility. The question about the wet nurse herself and her child is at this point not answerable. These are subjects of future research. Questions concerning childcare, motherly love, infant mortality and improved survival rates are closely connected to the hiring of wet nurses. To consider the wide variety of sources of German-speaking Europe may answer many questions in this neglected area of research and will open up additional points of view.

Sünje Prühlen is postdoctoral research fellow at the Department of Humanities and Social Sciences, Helmut Schmidt University, University of the Federal Armed Forces Hamburg, Germany.

59 Chaja Brodsky, Beobachtungen über die Lactation der Amme, (Diss. Zürich, 1914, Stuttgart, 1915); Johannes Laurentius, Zur Leistungsfähigkeit der Brustdrüse der Ammen (Diss. Leipzig, 1911, ibid., 1912). 


\section{References}

Album Academiae Helmstadiensis, ed. by Paul Zimmerman, 1, 1, Leipzig, 1926, Reprint Nendeln, 1980.

Altmann, Reinhold, Über die Inactivitätsatrophie der weiblichen Brustdrüse. Diss. Munich 1888, Berlin, 1888.

Arnold, Klaus, "Kindertotenbilder: Neue Zugänge zu Leben und Tod von Kindern im späten Mittelalter und in der frühen Neuzeit", pp. 208-222 in K. W. Alt, A. Kemkes-Grottenthaler, eds., Kinderwelten, Köln, 2002.

Arnold, Klaus, Kind und Gesellschaft in Mittelalter und Renaissance. Paderborn, 1980.

Beintker, Erich (Transl.), Galenos Gesundheitslehre, Vol. 1-3, Stuttgart, 1939.

Benedictow, Ole J., "On the Origin and spread of the Notion that Breast-Feeding Women should abstain from sexual Intercourse". Scandinavian Journal of History 17 (1992), 65-76.

Bernheim, Hugo, "Schwankungen der Sterblichkeit in Bayern und Sachsen und deren Faktoren", Zeitschrift für Hygiene 4 (1888), 525-581.

Borchers, Susanne, Jüdisches Frauenleben im Mittelalter. Die Texte des Sefer Chasidim. Diss., Köln 1998, Frankfurt/Main, 1998.

Brockmann, Johanna-Luise, "Ammentätigkeit in Deutschland (1750-1925). Eine Problemskizze zu einem vernachlässigten Thema der Sozialgeschichte“, Zeitschrift für Pädagogik 28 (1982), 695-714.

Brodsky, Chaja, Beobachtungen über die Lactation der Amme. Diss. Zürich, 1914, Stuttgart, 1915.

Brüning, Hermann, Geschichte der Methodik der künstlichen Säuglingsernährung, nach medizin-, kultur-und kunstgeschichtlichen Studien. Stuttgart, 1908.

Corpus Hippocraticum, De natura pueri.Ehestandsartzneybuch. Erfurt, 1542.

Erasmus, Alberus, Das Ehbüchlein. Frankfurt/Main, 1539.

Feis, Oswald, "Bericht aus dem Jahre 1411 über eine Hebamme, die angeblich 7 Kaiserschnitte mit gutem Erfolg für Mutter und Kind ausgeführt hat", Sudhoffs Archiv für Geschichte der Medizin, 20 (1928, Reprint 1965), 340-343.

Fildes, Valerie, "The English Wet nurse and her role in infant care 1538-1800", Medical History 21 (1988), 142-173.

Fildes, Valerie, Wet-Nursing. A history from antiquity to the present. Oxford, 1988.

Fildes, Valerie, Breasts, Bottles and Babies. A History of Infant Feeding. Edinburgh, 1986.

Fues, Wolfram M., "Amme oder Muttermilch? Der Disput um das Stillen in der frühen deutschen Aufklärung", Aufklärung, 5 (1990), 76-126.

Galle, Richard (Ed.), Konrad Bitschins Pädagogik. Gotha, 1905. 
Gray, Ursula, Das Bild des Kindes im Spiegel der altdeutschen Dichtung und Literatur. Frankfurt/Main, 1974.

Green, Monica H. (Transl.), The Trotula. A Medieval Compendium of Women's Medicine. Philadelphia, 2001.

Grimm, Jacob and Grimm, Wilhelm, Deutsches Wörterbuch, 1. Leipzig, 1854.

Hermann, Max (Ed.), Albrecht von Eyb, Ehebüchlein. Berlin, 1890.

Hill, Gerry, et al., "The Medical and Demographic Importance of Wet-Nursing", Canadian Bulletin of Medical History 3 (1987), 183-193.

Hooper, Bari, "A Medieval Depiction of Infant-feeding in Winchester Cathedral”, Medieval Archaeology 4 (1996), 230-233.

Kamann, J., Nürnberger Haushaltungs- und Rechnungsbücher aus dem 15. und 16. Jahrhundert. Nürnberg, 1888.

Keck, C. and Kissel, C., "Regulation der Laktation", Gynäkologische Endokrinologie 3 (2004), 127-132.

Knefelkamp, Ulrich, Das Gesundheits- und Fürsorgewesen der Stadt Freiburg im Breisgau im Mittelalter. Freiburg/Breisgau, 1981.

Knodel, John and Hallie Kintner, "The Impact of Breast feeding patterns on the biometric analysis of Infant Mortality", Demography 4 (1977), 391-409.

Koletzko, Bertold and Lehner, Frauke, "Beer and Breastfeeding", pp. 23-28 in B. Koletzko, et al., eds., Short and Long Term Effects of Breastfeeding an Child Health. New York, 2000. (Advances on experimental medicine and biology 478).

Krüger, Sabine (Ed.), Konrad von Megenberg, Ökonomik. Book I. (Stuttgart, 1973). (Monumenta Germaniae Historica, Scriptores III, 5/1).

Laufenberg, Heinrich, Versehung des leibs (Augsburg, 1491).

Laurentius, Johannes, Zur Leistungsfähigkeit der Brustdrüse der Ammen. Diss. Leipzig, 1911, ibid., 1912.

Litz, Gudrun (ed.), "Familienbüchlein Spengler", pp. 361-402 in Berndt Hamm, Lazarus Spengler (1479-1534), (Tübingen, 2004).

Matthews Grieco, Sara F., "Breastfeeding, Wet Nursing and Infant Mortality in Europe (1400-1800)", Historical Perspectives on Breastfeeding (Florence, 1991), $15-62$.

Mauch, Adolf (Transl.), Paolo Baggelardi, Libellus de Aegrituditudinibus infantium, Padua 1472. Bottrop, 1937.

Mayr, Georg, 'Die Sterblichkeit der Kinder während der ersten Lebensjahre in Süddeutschland, insbesondere in Bayern', Zeitschrift des königlich Bayerischen statistischen Bureau 2 (1870), 201-247.

McLaren, Dorothy, "Marital fertility and lactation 1570-1720", pp. 22-53 in M. Prior, ed., Women in English society 1500-1800. London, 1985. 
McLaren, Dorothy, "Nature's contraceptive. Wet-Nursing and prolonged lactation: he case of Chesham, Buckinghamshire 1578-1601", Medical History 23 (1979), 426-441.

McNeilly, Alan S., "Lactational Endocrinology: The Biology of LAM", Advances in experimental medicine and biology 503 (2002), 199-206.

Meier, Frank, Mit Kind und Kegel: Kindheit und Familie im Wandel der Geschichte. Ostfildern 2006.

Metlinger, Bartholomäus, Ein regiment der jungen kinder. Facsimile of the print from 1497. Zürich, 1976.

Metlinger, Bartholomäus, Ain vast nutzlich regiment der iungen kinder. Augsburg, 1511.

Michaelis de Vasconcellos, Carolina, "Randglossen zum altportugiesischen Liederbuch”, Zeitschrift für romanische Philologie, 20 (1896), 145-218.

Mollay, Karl (Ed.), Die Denkwürdigkeiten der Helen Kottanerin (1439-1440). Wien, 1971.

Pinther, Marc (Ed.), Die“Kinderzucht des Hieronymus Schenck von Siemau“ (1502). Hamburg, 1996.

Platter, Thomas, Hirtenknabe, Handwerker, Humanist. Die Selbstbiographie 1499 bis 1582, Heinrich Boos, ed. Nördlingen, 1989.

Prühlen, Sünje, "Alse sunst hir gebruchlich is". Bochum, 2005.

Riedel, Carl-Ludwig (Ed.), Conrad Gesner, Büchlein von der Milch und den Milchprodukten. Libellus de lacte, et operibus lacteriis, philologus pariter ac medicus. Mönchengladbach, 1996.

Rosenbaum, Ute, Liebestätigkeit und Armenpflege in der Stadt Zwickau. Ein sozialhistorischer Abriss von Mittelalter und beginnender Neuzeit. Hamburg, 1999.

Schadewaldt, Hans, Geschichtliche Übersicht über die zur Säuglingsernährung verwandten Geräte. Wissenschaftliche Ausstellung, 54. Tagung der Deutschen Gesellschaft für Kinderheilkunde 1954.

Schedel, Hartmann, Hartmann'sche Familienbuch/Familienchronik. Staatsbibliothek Berlin, Cod. Germ. $2^{\circ} 4472$.

Schedel, Hartmann, Weltchronik. Nuremberg, 1493.

Schiel, Hubert (Transl.), Erasmus von Rotterdam, Vertraute Gespräche (Colloquia familiaria). Stuttgart, 1985.

Schmitt, Wolfram, Bartholomäus Scherrenmüllers Gesundheitsregimen (1493) für Graf Eberhart im Bart. Diss. Heidelberg, 1970 [typescript].

Schrader, L.A.G., "Beherzigungen über die moralischen und politischen Folgen des Ammendienstes in großen Städten auf die umherliegenden Distrikte", Schleswig-Holsteinische Provinzialberichte 1 (1787), 457-461. 
Stauber, Richard, Die Schedelsche Bibliothek. Ein Beitrag zur Geschichte der Ausbreitung der italienischen Renaissance, des deutschen Humanismus und der medizinischen Literatur. Freiburg, 1908, Reprint Nieuwkoop, 1969.

Temkin, Owsei (Transl.), Soranus' Gynecology. Baltimore/London, 1991.

Thompson, C.R. (Transl.), Collected Works of Erasmus, Colloquies. Toronto 1997.

Trautmann, Gottfried, Der Kaiserschnitt des Jeremias Trautmann im Jahre 1610. Wittenberg, 1978.

Tscharner-Aue, Michaela von, Die Wirtschaftsführung des Basler Spitals bis zum Jahre 1500. Basel 1983. 